\title{
Pre-Service Teachers' Knowledge Regarding the Area of Triangle
}

\author{
Asli Bilik Durmaz ${ }^{1 *}$ (1), Mine Isiksal Bostan ${ }^{2}$ (1) \\ ${ }^{1}$ Namık Kemal Middle School, Şehitkamil, Gaziantep, TURKEY \\ 2 Middle East Technical University, Ankara, TURKEY \\ * Corresponding author: aslibilik01@gmail.com
}

Received: 1 May $2021 \bullet$ Accepted: 5 Jan. 2022

Citation: Bilik Durmaz, A., \& Isiksal Bostan, M. (2022). Pre-Service Teachers' Knowledge Regarding the Area of Triangle. European Journal of Science and Mathematics Education, 10(2), 208-224. https://doi.org/10.30935/scimath/11716

\begin{abstract}
:
The aim of this study is to investigate the knowledge of pre-service middle school mathematics teachers on possible misconceptions and difficulties held by students regarding the area of triangle. In line with this aim, qualitative case study research design was used to obtain deep information. As the participants of the study, two pre-service middle school teachers were chosen purposively. Data were collected from lesson plans, semi-structured interviews and observations of pre-service teachers' related lessons. The findings of the study showed that the pre-service teachers specified various misconceptions and difficulties regarding the area of triangle that might be observed among middle school students. When the determined misconceptions and difficulties were reviewed, it attracted attention that most of the misconceptions and difficulties were related to the concept of height. One of the findings of the study differed from other relevant studies in the respect that one of the pre-service teachers stated that students have the perception that $a$ line segment cannot be extended. Difficulties and misconceptions and the reasons of them are discussed accordingly.

Keywords: pre-service teachers, mathematics education, pedagogical content knowledge, area of triangle, misconception
\end{abstract}

\section{INTRODUCTION}

Learning of mathematics is related to effective teaching, and teachers have a crucial role in this process (National Council of Teachers of Mathematics [NCTM], 2000). In this regard, teacher knowledge plays a key part in teaching mathematics properly (Hill et al., 2004). In this respect, researchers have examined for many years the components of teacher knowledge required for effective teaching. As a cornerstone, Shulman (1986) stated that all of the previous studies with regard to teacher knowledge put emphasis on classroom management, time allocation and lesson planning. However, questions about teacher explanations, decisions about how to teach, what to teach and how to overcome difficulties and misconceptions remained unanswered. Based on his judgment, the term pedagogical content knowledge (PCK) was introduced. Shulman (1987) identified seven categories of knowledge: subject matter knowledge, general pedagogical knowledge, pedagogical content knowledge, knowledge of students, knowledge of curriculum, knowledge of educational context, and knowledge of educational purposes. After Shulman, other researchers have conducted a large number of studies to examine the components of PCK (Ball et al., 2008; Grossman, 1990; Magnusson et al., 1999; Marks, 1990; Park \& Oliver, 2008; Rowland et al., 2009; Tamir, 1988). Table 1 outlines many of PCK models with various sub-components conceived by various scholars. Among all sub-components, students' learning and conceptions were conceptualized by all of the researchers.

This study is a part of the first author's master's thesis. 
Table 1. Different conceptualizations of PCK (Lee \& Luft, 2008, p. 1346)

\begin{tabular}{|c|c|c|c|c|c|c|c|c|}
\hline \multirow[b]{2}{*}{ Reference } & \multicolumn{8}{|c|}{ Knowledge of } \\
\hline & $\begin{array}{l}\text { Subject } \\
\text { matter }\end{array}$ & $\begin{array}{c}\text { Representations \& } \\
\text { instructional } \\
\text { strategies }\end{array}$ & $\begin{array}{c}\text { Student } \\
\text { learning \& } \\
\text { conceptions }\end{array}$ & $\begin{array}{l}\text { General } \\
\text { pedagogy }\end{array}$ & $\begin{array}{l}\text { Curriculum } \\
\text { \& media }\end{array}$ & Context & Purpose & Assessment \\
\hline Shulman (1987) & a & PCK & PCK & a & a & $\mathrm{a}$ & a & $\mathrm{b}$ \\
\hline Tamir (1988) & a & PCK & PCK & a & PCK & $\mathrm{b}$ & $\mathrm{b}$ & PCK \\
\hline Grossman (1990) & a & PCK & PCK & a & PCK & a & PCK & $\mathrm{b}$ \\
\hline Marks (1990) & PCK & PCK & PCK & $\mathrm{b}$ & PCK & $b$ & $\mathrm{~b}$ & $\mathrm{~b}$ \\
\hline Cochran et al. (1993) & PCKg & B & PKCg & PCKg & $\mathrm{b}$ & PCKg & $\mathrm{b}$ & $\mathrm{b}$ \\
\hline $\begin{array}{l}\text { Fernandez-Balboa and } \\
\text { Stiehl (1995) }\end{array}$ & PCK & PCK & PCK & $\mathrm{b}$ & $\mathrm{b}$ & PCK & PCK & b \\
\hline Magnusson et al. (1999) & a & PCK & PKC & a & PCK & a & PCK & PCK \\
\hline Carlsen (1999) & $\mathrm{a}$ & PCK & PKC & a & PCK & $\mathrm{a}$ & PCK & $\mathrm{b}$ \\
\hline Loughran et al. (2001) & $\mathrm{b}$ & PCK & PKC & $\mathrm{b}$ & PCK & $\mathrm{b}$ & PCK & PCK \\
\hline
\end{tabular}

a: distinct category in the knowledge base for teaching; b: not discussed explicitly; PCK: pedagogical content knowledge; PCKg: pedagogical content knowing

As another group of researchers, Rowland et al. (2009) highlighted the importance of information provided in lesson plans and of observing the ongoing learning environment to identify teachers' knowledge in mathematics. Their purpose was to understand which types of teacher knowledge were used during active teaching. In line with their purpose, a practice-based framework named knowledge quartet was specified to identify pre-service teachers' mathematical content knowledge. In their study, Rowland et al. (2003) developed a knowledge quartet framework with four dimensions, namely foundation, transformation, connections and contingency. As one of the dimensions, foundation reflects teachers' mathematical content knowledge, their understanding of mathematics and beliefs about why students learn mathematics topics and how they best learn mathematics (Weston et al., 2012). In brief, it is what teachers learn at their school or at university (Rowland, 2013). The second dimension is transformation, which is pertinent to teachers' knowledge and used during planning or in the act of teaching (Rowland, 2013). It enables teachers to convey their content knowledge to students in the most understandable way (Weston et al., 2012). The third dimension is defined as connection. Teachers' decisions about concept sequencing, the connections they make between procedures and concepts and their anticipation about what is difficult for the students are placed under this dimension (Weston et al., 2012). The last dimension, contingency, includes teachers' decisions about unexpected events or unexpected answers of the students within ongoing teaching environment (Rowland, 2013). In brief, Rowland et al. (2009) developed a teachers' knowledge model by observing pre-service elementary mathematics teachers' ongoing teaching and also examining lesson plans for corresponding lessons. Therefore, pre-service teachers' knowledge on students' misconceptions and difficulties was investigated based on the knowledge quartet model in the current study.

One of the important learning areas in mathematics curriculum is measurement (Fidan \& Turnuklu, 2010; NCTM, 2014), because it is more connected with real life settings among other mathematical learning areas (Baturo \& Nason, 1996). Besides, measurement supports students in quantifying and making sense of the world (Tan-Sisman \& Aksu, 2012). However, students face with difficulties in understanding the measurement domains because of rote memorization of the rules and limited prototypes of geometrical shapes (Fujita \& Jones, 2007; Yenilmez \& Yasa, 2008).

Studies investigating students' misconceptions regarding measurement domains show that students do not understand the rationale underlying the measurement concepts (Tan-Sisman \& Aksu, 2012), and could not explain why people multiply base and height while calculating the area of a rectangle (Huang \& Witz, 2013). Since students do not understand area conceptually, they do not know where the area formula comes from or why such a formula exists (Machaba, 2016). Moreover, while calculating the area of a triangle, students could forget to divide by two or they could multiply the three sides of the triangle (Cavanagh, 2008; Gokdal, 2004). In addition, when the area of a parallelogram was asked for, students divided the multiplication of the height and the side by two (Orhan, 2013). 
In this respect, for meaningful learning, teachers have an important role so that if they are aware of students' difficulties and misconceptions about the concepts, and if they know the reasons behind these misconceptions and difficulties; then, they can create a meaningful learning environment for students (Baturo \& Nason, 1996; Yeo, 2008). In this regard, teacher training features a critical role in equipping pre-service teachers with required knowledge (Borko et al., 1992; Van Steenbrugge et al., 2014). However, previously conducted studies show that pre-service teachers have inadequate knowledge regarding students' misconceptions and difficulties on specific mathematics topics (Gokkurt et al., 2015; Kilic, 2011; Kubar \& Cakiroglu, 2017; Tanisli et al., 2013; Simsek, 2011). To provide convenient knowledge for teacher educators and policy makers, more attention should be given to pre-service teachers. Hence, teacher education courses and their contents can be managed according to requirements. Therefore, prospective teachers' knowledge on students' misconceptions and difficulties was investigated in this study.

Over years, several studies have been conducted to investigate the PCK of pre-service and in-service teachers on several topics in mathematics, such as algebra (Dede \& Peker, 2007; Tanisli et al., 2013), statistics (Burgess, 2006), fractions (Aksu \& Konyalioglu, 2015; Isiksal \& Cakıroğlu, 2011; Karaagaç \& Kose, 2015), variables (Sahin et al., 2016), integers (Kubar, 2012), and functions (Karahasan, 2010). In terms of studies conducted on mathematics topics regarding measurement, researchers focus on quadrilaterals (Aslan-Tutak \& Adams, 2017; Nur \& Turnuklu, 2015), solid objects (Bukova-Guzel, 2010), length (Simsek \& Boz, 2015), geometrical shapes (Gokkurt et al., 2015; Yurtyapan \& Karatas, 2020), relationships between area and perimeter (Deniz-Yilmaz \& Kucuk-Demir, 2021; Simsek, 2011; Yeo, 2008), area (Runnalls \& Hong, 2019) and volume (Tekin- Sitrava, 2014). When the relevant literature was reviewed, it was noticed that there is an insufficient number of studies regarding the area concept. However, results of the conducted studies revealed that area is the most compelling and complicating concept for students among other measurement concepts (Kamii \& Kysh, 2006; Orhan, 2013; TanSisman \& Aksu, 2009; Zacharos, 2006).

The studies in the related literature concerning the area concept are mainly about pre-service teachers' responses about the mistakes made by students on the calculation of the areas of rectangle and irregular shapes (Runnalls \& Hong, 2019), pre-service teachers' subject matter knowledge on area concept regarding rectangle, triangle and circle (Baturo \& Nason, 1996), their PCK on the area and perimeter of rectangle and square (Simsek, 2011; Yeo, 2008), their PCK on the relationship between the areas and perimeters of rectangles, squares, and parallelograms (Deniz-Yilmaz \& Kucuk-Demir, 2021; Livy et al., 2012), and pre-service teachers' understanding of the height of triangle (Gutiérrez \& Jaime, 1999). As it can be seen, researchers have focused mostly on the relationship between area and perimeter and the area of rectangular shapes in their research studies. There was no study concerning pre-service teachers' PCK specifically on the area of triangle in the accessible literature. Thus, there is a room for research studies that focus on triangles which could present invaluable implications to the teacher educators and policy makers in developing pre-service teachers' knowledge. In this regard, the aim of this study is to examine pre-service teachers' knowledge of misconceptions and difficulties held by students regarding the area of triangle.

In the light of this aim, the following research question guided the study:

What do pre-service middle school mathematics teachers know about the misconceptions or difficulties held by sixth-grade students related to the area of triangle?

\section{METHOD}

Qualitative case study research design was used in this study in order to look at pre-service teachers' knowledge of misconceptions and difficulties experienced by students about the area of triangle. Case study is defined as "an exploration of a bounded system or a case (or multiple cases) over time through detailed, in-depth data collection involving multiple sources of information rich in context." by Creswell (1998, p. 61). 
In this regard, two pre-service middle school mathematics teachers constituted the cases of the study. Participants were studying in a middle school mathematics teacher education program in one of the public universities in Ankara province of Turkey, and they were in their last year of education.

\section{Context of the Study}

Undergraduate middle school mathematics teachers' education program constitutes the context of the study. The program lasts four years and the language of education is English. While the courses for the first two years in the program are about pure mathematics and science, education courses are in the foreground for the following years. Pre-service teachers attend Methods of Teaching Mathematics I and II courses in their third year. By means of these courses, pre-service teachers learn how to plan a lesson with different teaching strategies, and students' misconceptions related to mathematics learning areas are discussed and analyzed. In their first semester of the last year in the program, pre-service teachers take a school experience course. By means of this course, they participate in real classrooms at their assigned internship schools and make observations during teaching. In the following semester, preservice teachers enroll in a teaching practice course. Hence, they have a chance to observe and have some teaching experience in real classrooms.

Moreover, participants' internship schools should be taken into account in the context of the study. The teaching practice school was a public middle school, and education in this school was in the form of double shift schooling. The classes where the pre-service teachers and the first author attended during teaching practice were the sixth graders' classes. Moreover, each class consisted of 30-35 students, and smart boards or any other technological tools were not available in these classes.

\section{Participants}

Purposive sampling was used to collect data. The selection of the participants builds upon some reasons. One of the reasons is that since senior pre-service teachers had taken all their compulsory educational courses until their last semester, they were assumed to be valuable sources of data for the study. Another reason is that observation in a real classroom setting was important for the study, and undergraduate students in their last year of education have an opportunity to attend and teach in a real classroom at their internship schools by means of school experience courses. Therefore, participants were chosen from students who were at their last year of university education. In addition, another important factor for the researchers was easy access to the participants. Since the first author was required to spend a considerable amount of time with the participants for lesson planning, conducting pre- and postinterviews and observing their teaching classes, easy access to the participants was important for the first author. Keeping those criteria in mind, two female pre-service middle school mathematics teachers, who were in their last semester of the undergraduate program, and enrolled in the middle school mathematics teacher education program, constituted the participants of the study. Pseudonyms were given to both participants to protect the confidentiality of the collected data. In this respect, for the pseudonyms, Hatice and Eda were chosen for the teachers. Both participants completed the must courses of the program and enrolled in the school experience course in their last semester of the school.

\section{Data Collection}

Initially, the first author met with the two pre-service teachers to ask them whether they would volunteer to participate in the study. In this respect, the purpose of the study was explained to them. In addition, data collection process was clarified. Since video shoots using a video camera for classroom observations and interviews would be made, the participants were informed about the process. Then, participants signed the informed consent form. To gain information-rich data concerning pre-service teachers' knowledge regarding students' misconceptions on the area of triangle, three types of data collection methods were used. Those methods were lesson planning in document form, observation and interviewing. 
As the first data collection tool, the first author asked pre-service teachers to prepare a lesson plan for four class lessons regarding the area of triangle for sixth graders that they teach in their internship school. It was also added that the questions and the problems planned to be asked during instruction were important to be involved in lesson plans in order to gather deep information.

As the second data collection tool, semi-structured interviews were conducted with the two pre-service teachers before and after the observation of lessons. Moreover, interviews were recorded on video. The first part of the interviews was reserved for prepared lesson plans. Hence, the first author had a chance to gain insight into the reasons behind prepared questions and problems. In this regard, pre-service teachers were asked the following questions: "How did you plan the lessons?"; "What are the critical elements of your lesson plan?" Moreover, if the pre-service teacher prepared a question or a problem in her lesson plan that evokes a difficulty or a misconception of students, then it was asked "why it was important to ask such a question or problem", and "what can be the other students' difficulties or misconceptions regarding the area of triangle?" to identify prospective teachers' knowledge before their actual teaching. After the first part of the interviews, four teaching practices of each participant regarding the area of triangle were observed and recorded on video at their internship schools. Following the classroom observations of the pre-service teachers, post-interviews were carried out with them. Hence, the preservice teachers had the chance to explain their reasoning regarding the events taking place during observed lessons. Some of the directed questions were "Did you experience any misconception or difficulty of students during teaching?", "Was there any misconception that you experienced for the first time?", "Was there any other misconception or difficulty of the students regarding the area of triangle?". Moreover, to reveal pre-service teachers' knowledge on students' misconceptions and difficulties underlying students' incorrect answers, the questions "what do you think about the student's solution?", "why do you think that the student solved the problem like this?", and "what can be the reason for the student's incorrect solution?" were asked.

As the last data collection tool, observations of the lessons were conducted. By means of observation, the first author had a chance to investigate pre-service teachers' PCK in an ongoing learning environment.

In this respect, four lessons of each participant were observed, and the observed lessons were videotaped. Moreover, the first author took notes according to certain criteria determined previously in accordance with the aim of the study. For instance, during the teaching practice, whenever students developed a misconception or had a difficulty while solving a problem or answering a question, the first author took notes about whether the pre-service teacher realized students' misconception or difficulty. Then, during the post-interviews, video recordings of parts of the lessons associated with the taken notes were shown to the pre-service teachers. Hence, they had a chance to express the rationale behind the sentences and the behaviors.

\section{Data Analysis}

Constant comparative method was used as the analysis method of the study. In this respect, the prepared lesson plans for teaching practice, conducted interviews, and the eight observed lessons of the two pre-service teachers were analyzed to investigate pre-service teachers' knowledge on students' misconceptions and difficulties regarding the area of triangle. Initially, the video recordings of the first parts of the interviews, post-interviews and classroom observations were transcribed. Then, all the data sources were examined one by one. In this regard, the data reflecting teachers' knowledge on students' misconceptions and difficulties were selected and irrelevant data were eliminated from the transcription. After that, the data resembling each other were gathered together and possible codes were determined. The data sources were examined continuously until no new codes emerged. Then, the codes were compared with others and similar codes were brought together to be merged under specific themes. Afterwards, an expert who is an instructor in mathematics education department also checked the obtained codes and themes. 


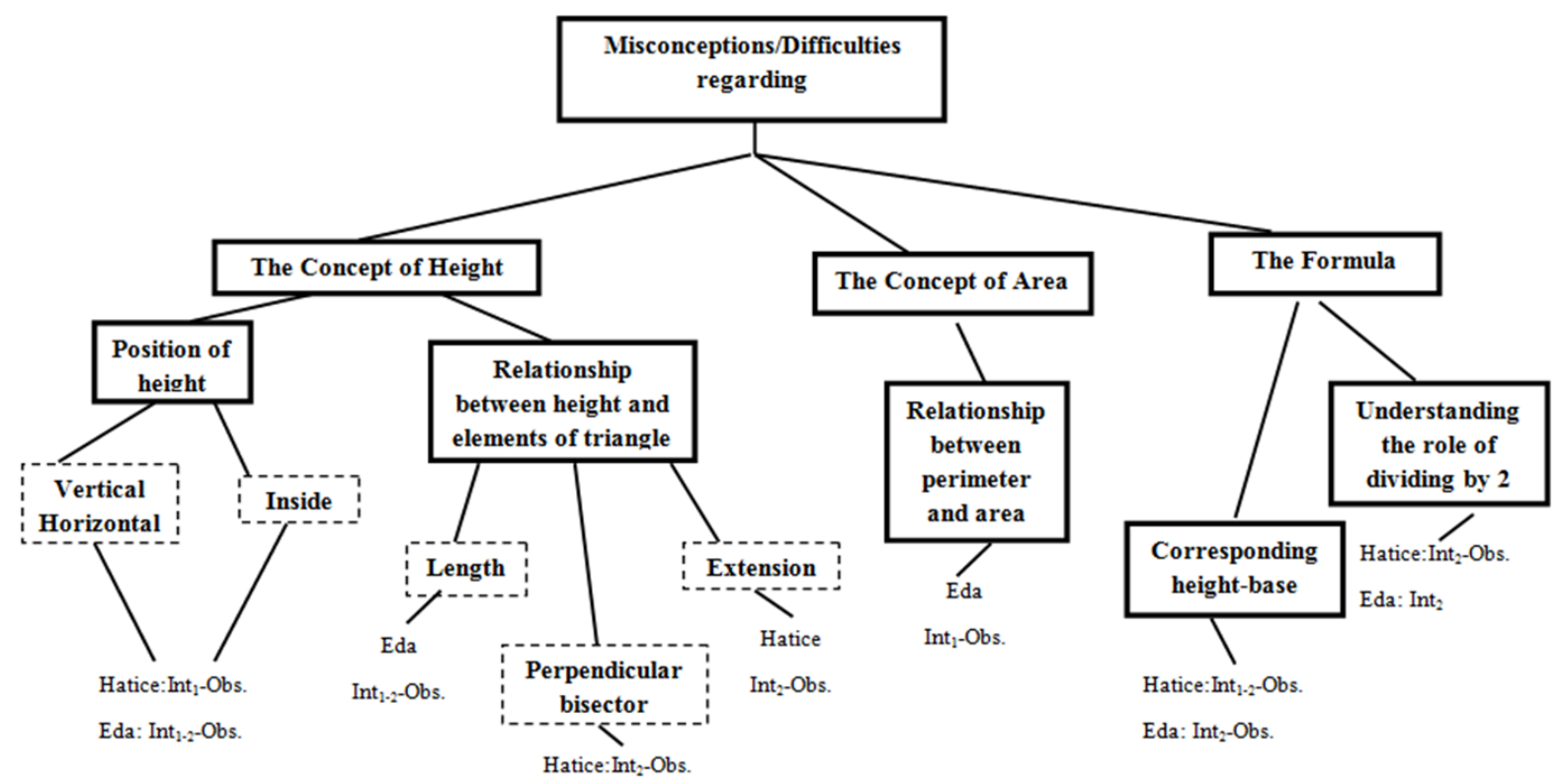

Figure 1. Summary of misconceptions/difficulties specified by the two pre-service teachers

\section{Researcher's Role and Bias}

The first author was a non-participant observer during the classroom observations. To avoid researcher effect on the students and pre-service teachers, classes were observed and recorded on video by a camera for a while before real observation. By this way, the interaction with the first author and participants was enhanced before data collection. The first author explained the aim of the study and the participants had the right to withdraw from the study whenever they wanted.

\section{FINDINGS}

The aim of this study is to examine pre-service elementary mathematics teachers' knowledge of students' misconceptions and difficulties regarding the area of triangle. In this respect, prepared lesson plans, interviews and classroom observations were analyzed to acquire data.

Data analysis revealed that pre-service teachers specified a large number of possible misconceptions and difficulties that students may have. Figure 1 summarized the list of the misconceptions and difficulties provided by the two pre-service teachers. Pre-service teachers' knowledge regarding students' misconceptions/difficulties in the concept of the area of triangle could be categorized under three main themes and relevant codes. These main categories are namely misconceptions/difficulties regarding the height, regarding the area and regarding the formula. In this regard, they were explained in a detailed manner under separate sections.

\section{Difficulties/Misconceptions Regarding the Concept of Height}

Based on Figure 1, it is noticeable that the two pre-service teachers identified numerous misconceptions and difficulties about the concept of height. According to the pre-service teachers' specifications about the misconceptions and difficulties related to the concept of height, two subcategories were formed, namely misconceptions/difficulties regarding the position of height and misconceptions and difficulties regarding the relationship between the elements of the triangle and height. Under the misconceptions and difficulties related to the position of height, two of the specified student misconceptions were categorized. These are the height should always be inside the triangle and the height should always be either vertical or horizontal. As for the other subcategory, three misconceptions and difficulties were included among the misconceptions and difficulties specified by the two pre-service teachers. To be specific, they underlined students' possible thoughts about the relationship between the elements of the triangle and 

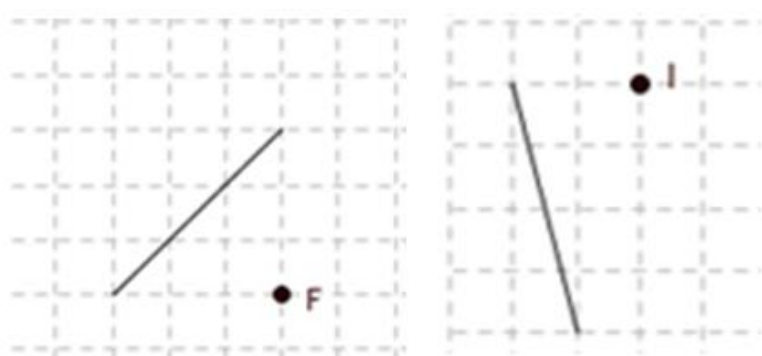

Figure 2. Figure of a question from the lesson plan of Hatice

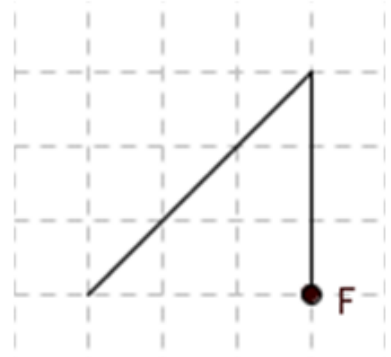

Figure 3. Hatice's presentation of a possible construction by a student

height, namely height is a perpendicular bisector of the base, the side of a triangle cannot be extended, and confusion of the concepts of length and height, in other words, the hypotenuse of a triangle is the height of it. These misconceptions/difficulties were examined below with excerpts taken from the prepared lesson plans, observations or interview transcripts.

\section{Misconceptions and Difficulties Regarding the Position of the Height}

During the first part of the interviews, both participants were asked about for what purpose they prepared their questions in their lesson plans. In this respect, they expressed that some of the prepared questions were asked to determine if students had the misconception that 'height is always vertical or horizontal to the ground.' To show, the corresponding question below is taken from Hatice's lesson plan.

Question: Draw the perpendiculars from point F and I to the line segments (Figure 2).

During the examination of her lesson plan, it was realized that Hatice presented some expected answers of students regarding the questions and the possible rationale behind the answers. For instance, for point F, students may draw a perpendicular line segment vertically as shown in Figure 3, since they had a thought such that a perpendicular line segment will always be vertical.

Moreover, for the points G and I, students may draw the perpendicular line segments horizontally as shown in Figure 4 for the reason of thought that a perpendicular line segment will always be horizontal.

During the first part of the interviews, Hatice clarified the reason behind the prepared questions given above as follows:

The aim of the questions above is to enable students to understand that height is a perpendicular line segment and can be constructed on any base. Students think that altitude should be vertical. Thus, they could not understand how they could draw altitudes to all the sides of the triangle, especially which are not vertical (From the lesson plan of Hatice). 


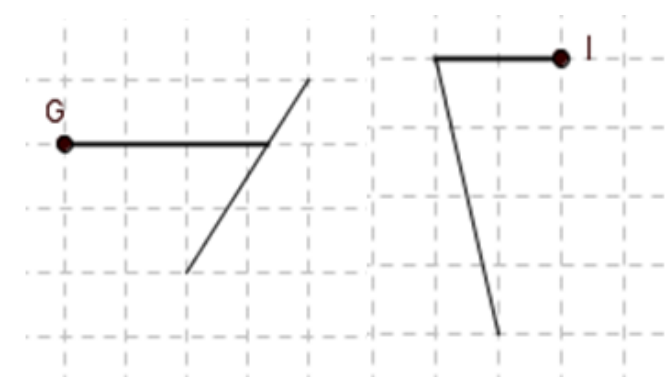

Figure 4. Hatice's presentation of possible constructions by a student

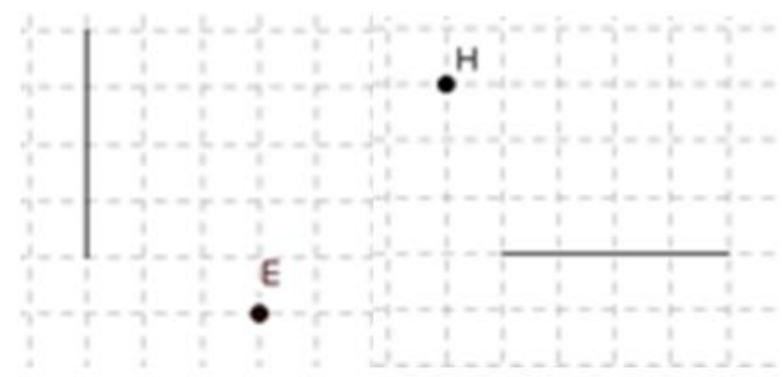

Figure 5. Figure of a question from the lesson plan of Hatice

As Hatice, Eda also planned to ask the question 'Is it always vertical or horizontal?' to the students in her lesson plan. This question reflected that Eda holds the knowledge of students' misconception that height is always vertical or horizontal to the ground.

Moreover, both pre-service teachers stated that students might have a misconception such that the height should always be inside the triangle. Accordingly, participants' knowledge of the students' misconception could be seen in their lesson plans. For example, Eda planned to ask students the question 'Is the height always inside the triangle?' which was written in her lesson plan. Eda was questioned during the first part of the interview to clarify the reason for asking such a question. Eda's answer is given below:

Height in the obtuse triangle might not be distinguished by the students, that is, where the height needs to be drawn, whether inside or outside, or if it can be outside. I thought that more emphasis should be placed on this topic to prevent the perception that the height can only be inside the triangle and cannot be outside of the triangle (Eda-Int1).

Hatice mentioned in her lesson plan another misconception encountered while asking students to draw perpendiculars from given points to line segments as provided in Figure 5. The rationale behind the provided questions were explained by Hatice during the first part of the interviews, as follows:

Students can suppose that height should always be on the line segment and they can answer the question erroneously (Hatice-Int 1 ).

The prepared questions in lesson plans and the answers taken from the interviews clearly indicated the knowledge of the two pre-service teachers on students' possible misconceptions regarding the views that height is always vertical or horizontal to the ground and height is always inside the triangle. Up to now, pre-service teachers' knowledge on students' possible misconceptions regarding the position of height was examined. The other misconception related to height, that is, the pre-service teachers' knowledge of students' misconceptions about the relationship between the height and the elements of the triangle, is presented in the next section. 
Question:

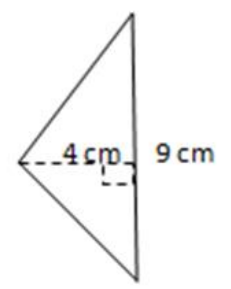

Find the area of the triangle.

Figure 6. Figure of a question from the lesson plan of Eda

\section{Misconceptions and Difficulties Regarding the Relationship between the Height and the Elements of the Triangle}

During the post-interviews that were arranged after the lessons, the pre-service teachers stated that students may have a perception such that 'height is always a perpendicular bisector of the corresponding base'.

In this respect, Eda wrote the question as shown in Figure 6 to the board during her observed classroom teaching. Following that, a student's solution and Eda's explanations about that solution are given.

Solution of the student: The base is $9 \mathrm{~cm}$. When we divide it by two, it turns out to be $4.5 \mathrm{~cm}$ and $4.5 \mathrm{~cm}$.

Eda Teacher: Ayse divided the triangle into two parts. She wrote $4 \mathrm{~cm}$ for the height and $9 \mathrm{~cm}$ for the base. Hilal, you divided it into two as 4.5 and 4.5. However, have you been told that the triangle was isosceles or equilateral? Did you divide into two because of the appearance of the triangle?

Student A: Yes, because of its appearance.

Eda Teacher: Does the height always divide the base into two? For example, in this question did the height divide the base into two?

The class: Yes.

Eda Teacher: Now, look here. If the triangle in the question were an isosceles triangle or an equilateral triangle, then what Hilal said would be true. However, now we cannot assert that the height divides the base into two pieces as 4.5 and $4.5 \mathrm{~cm}$ (EdaObs.).

The pre-service teacher's knowledge on students' misconception that 'height is always a perpendicular bisector of the corresponding base' could be seen clearly from the classroom observation excerpt above. After the student's solution, the teacher asked the question 'have you been told that the triangle was isosceles or equilateral?'. By means of this question, Eda tried to understand the reason of the bisectioning of the base. If the answer was yes, in other words, if the triangle was isosceles or equilateral, then the base could be divided into two equal pieces. Hence, the students' confusion between height and perpendicular bisector cannot be noticed (Gutierrez and Jaime, 1999). However, the triangle was not mentioned as an isosceles or equilateral one. Since the pre-service teacher holds the knowledge of students' misconception that 'height is always a perpendicular bisector of corresponding base', she asked the question of 'Does the height always divide the base into two?' to determine whether the students have this misconception.

In addition to the provided misconception, during a teaching practice that was observed, Hatice realized that students have a perception such that a line segment cannot be extended. The excerpt below was given to show the dialogue between the students and the pre-service teacher. 


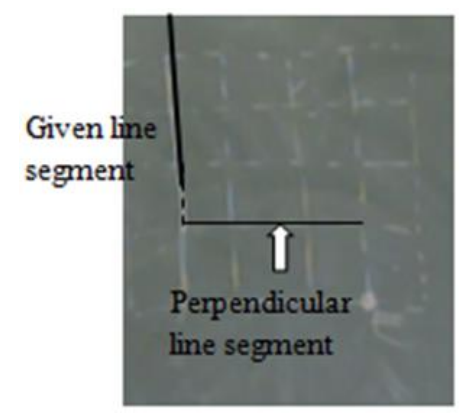

Figure 7. An example of students' answer from Hatice's lesson

Hatice Teacher: Draw a perpendicular line segment from point $\mathrm{E}$ to the given line segment.

Following the pre-service teacher's question, a student drew an extension of the line segment and the perpendicular line segment during the instruction as shown in Figure 7.

Student-B: It does not exist here (by implying the drawn extension)

Student-C: Is it a ray? (Referring to the line segment)

Hatice Teacher: A line segment

Student-C: I cannot draw it (implying the extension) if it is a line segment.

Hatice Teacher: Even so, state your idea about the question.

Student-C: I would draw the extension if it were a ray.... It can be extended since it is a ray.

Student-C: The thing that I could not understand was that we learned that the line segment does not extend. However, we extended it.

Hatice Teacher: It does not extend. We said it for the extension of the line segment.

During the post-interviews conducted to clarify questions about this lesson, the pre-service teacher stated that "Before the lesson, I did not think that students might have problems about the extension concepts. However, the students had unsatisfactory knowledge about the extension of a line segment.". In regard to the statement of Hatice, it can be asserted that the pre-service teacher had the knowledge of students' misconception that 'a line segment cannot be extended'.

In addition to the provided misconception above, the pre-service teachers stated that students may confuse the concepts of length and height. To be more specific, students may think that the hypotenuse of a right triangle can substitute the term length.

While analyzing the lesson plan of Eda, it was realized that a question was prepared to understand whether the students were able to distinguish the length from the height. In this respect, she stated during the first part of the interviews that

"When I thought about the difficulties the students experienced in relation to the concept of height, the confusion between the height and length came to my mind. That is why I tried to present them the ladder problem."

The relevant problem is provided below and drawn in Figure 8: 


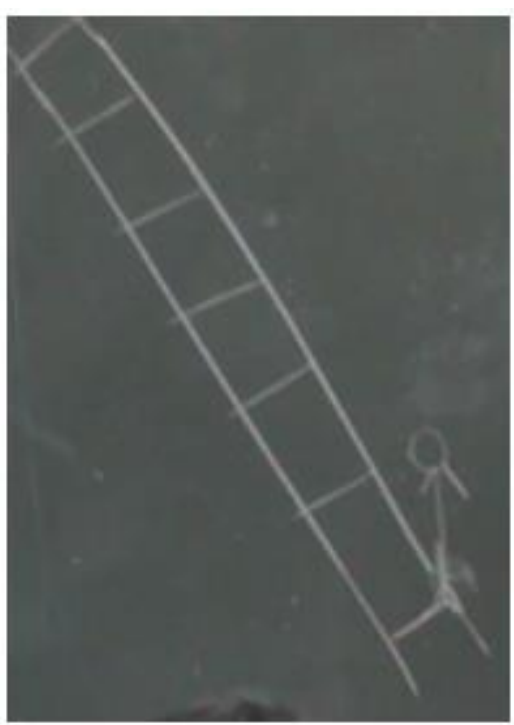

Figure 8. Presentation of the ladder problem from Eda's lesson

Problem: The painter wants to paint his house. Since he cannot reach the higher parts of the wall, he will use a ladder of $1.5 \mathrm{~m}$ length. When he ascends to the highest step of the ladder, what can be his height in relation to the ground? Show it by drawing on the shape.

Following the question statement, the pre-service teacher added that

"If students confused the length of the ladder and its height, then I would expect them to make this mistake, that the height of the painter on the last step of the ladder will be $1.5 \mathrm{~m}$ since the length of the ladder is $1.5 \mathrm{~m}$ " (Eda-Int 1 ),

and she continued stating that

"I think the length of the ladder here refers to the hypotenuse of the triangle, while the height of the painter from the ground refers to the height of the triangle. I think what the students may confuse could derive from these concepts" (Eda-Int 1 ).

The above statements of the pre-service teacher proved her knowledge on students' misconception regarding the confusion between the hypotenuse and the vertical height of a right-angled triangle.

\section{Misconceptions and Difficulties Regarding the Concept of Area}

Analysis of the data revealed that the pre-service teacher Eda had knowledge on the students' misconception that there is a direct relationship between the perimeter of the figure and its area. In the following part, the pre-service teachers' knowledge on the corresponding misconceptions is provided in detail.

\section{Misconceptions and Difficulties Regarding the Relationship between Perimeter and Area}

When the lesson plan of Eda was analyzed, it was realized that there was an activity to investigate the relationship between perimeter and area. In relation to that, Eda explained during the first part of the interviews the reason for preparing such an activity as follows:

Students may have a perception such that "by dividing a parallelogram into two equal pieces, its perimeter and its area are also divided by two". By means of the activity, students would realize that the area and the perimeter of a shape do not 


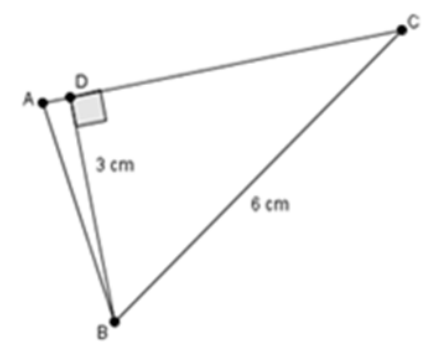

Problem: Ahmet found the_area of the triangle on the

left_side as $9 \mathrm{~cm}^{2}$ but he was not sure of his answer.

What do you_think_about his answer? Explain.

Figure 9. Figure of the problem from the lesson plan of Hatice

have a direct relationship. Hence, they would be able to differentiate the area from the perimeter (Eda-Int1).

In the light of the statements of Eda, it can be inferred that she holds the knowledge of the students' misconception that the perimeter of a shape has a direct relationship with its area.

\section{Misconceptions and Difficulties Regarding the Formula for the Area of a Triangle}

Analysis of the data indicated that the pre-service teachers had knowledge on students' misconceptions regarding understanding the role of dividing by two during calculating the area of a triangle and establishing the height and its corresponding base for the formula. In the following part, the pre-service teachers' knowledge on these misconceptions is provided in detail.

\section{Understanding the Role of Dividing by Two}

The pre-service teachers expressed that when students are calculating the area of a triangle, they multiply the base and its corresponding height, but skip the division by two. Regarding this, one of the pre-service teachers, Hatice, pointed out to the following statements during her post-interview:

During calculation, they think of the parallelogram. I think they think of the formula as the base multiplied by the height as in the formula of the area of the parallelogram. However, they cannot think that we divide the parallelogram into two. So, they forget to divide it by two (Hatice-Int2).

In addition, during one of the observed lessons of the other pre-service teacher, Eda, a student calculated the product of the base and the corresponding height, then divided the result by two twice. Regarding this circumstance, the pre-service teacher explained the difficulty experienced by the students, as follows:

Well, I think she got confused. We stated that half of the area of a parallelogram gives the area of the triangle. I think she got confused and divided the area of the triangle by two again. So, she confused the old information with the new one, since she had difficulty in understanding the role of two in the formula for the area of triangle (Eda-Int2).

\section{Establishing the Height and Its Corresponding Base}

Besides the difficulty related with ignoring the division by two during calculating the area of a triangle, one of the pre-service teachers, Hatice, stated that students may have a difficulty in establishing the height and its corresponding base for the formula. Accordingly, she gave place to a problem in her lesson plan (Figure 9) and clarified how students can solve it, as follows:

The students would say three multiplied by six divided by two. While finding the area, we multiply the base with the corresponding height and then it is divided by two. However, when the students see a height here, they will most probably directly 
multiply them and divide the result by two without thinking about the corresponding base (Hatice-Int 1 ).

The above expressions of Hatice could be accepted as a proof of her knowledge on the difficulty experienced by students in establishing the height and its corresponding base. Similarly, the other preservice teacher also indicated the same difficulty experienced by students. In this regard, her related expressions gathered from her post-interview are presented below:

The effect of height (regarding misconception/difficulty) was one related to the area of the triangle concept. Since students experienced difficulty in "specifying height and its corresponding base", they also struggled in the concept of area (Eda-Int2).

To sum up, the knowledge of the two pre-service teachers on students' possible misconceptions and difficulties regarding the area of triangles was investigated up to this point under three headings, namely misconceptions and difficulties regarding the concept of height, regarding the concept of area and regarding the formula for the area of triangle.

\section{DISCUSSION}

The aim of this study is to examine the knowledge of pre-service teachers on students' misconceptions and difficulties regarding the area of triangle. In line with this aim, pre-service teachers' knowledge on students' misconceptions and difficulties pertaining to the area of triangle was examined under three categories according to the statements of participants. These categories were determined as misconceptions and difficulties regarding the concept of height, regarding the concept of area and regarding the formula of the area of triangle. The misconceptions and difficulties of students specified by the pre-service teachers were also indicated by other researchers in the literature (Cavanagh, 2008; Gokdal, 2004; Orhan, 2013).

In this study, pre-service teachers specified the misconceptions of students related to height, as height should always be vertical or horizontal to the ground or inside the triangle. In fact, these misconceptions were similar with the misconceptions defined by Hershkowitz (1989). Hershkowitz (1989) expressed the reason behind students' perception that the height should always be inside the triangle with the concept image of triangle. To this end, acute triangles were always showed to students as examples, and these triangles had only internal heights (Hershkowitz, 1989). Hence, students might try to draw the height of a corresponding base inside the triangle unintentionally. In line with what Hershkowitz (1989) said, Gutierrez and Jaime (1999) expressed that, because of having partial concept images, students were able to draw internal height; however, they were not able to draw external heights or heights coinciding with the edges of triangles. The pre-service teachers' explanations about students' misconception were in parallel with the expressions of Hershkowitz (1989) and Gutierrez and Jaime (1999) regarding the possible reason underlying the students' misconceptions. The pre-service teachers stated that students usually do not experience different bases with varied illustrations of height or perpendicular line segments. Also, they were mostly asked questions about the height of a horizontal base. Therefore, students might develop a perception that the height should always be parallel or perpendicular to the floor.

Gutierrez and Jaime (1999) represented in their studies that some of the students confuse height with perpendicular bisector. As a reason of this confusion, they indicated partial concept images of students, so that students drew the heights at the center of the corresponding bases although the drawn heights were correct. As Gutierrez and Jaime (1999) mentioned, the pre-service teachers indicated that students might have a thought such that the height of the horizontal base appeared to be dividing the base equally. Therefore, they may have a misconception that height should be the perpendicular bisector of a side.

One of the pre-service teachers, Eda, also highlighted that students could not differentiate the concepts of height and length. The explanations of Eda were in parallel with the other relevant studies; for 
example, it was stated in the literature that students might not be able to distinguish the perpendicular height from the slant edge (Cavanagh, 2008).

One of the interesting findings of the study is about a possible misconception of students identified by the pre-service teacher Hatice. To clarify, the pre-service teacher specified that students might have a thought such that the side of a triangle cannot be extended, so the students might have difficulty in determining the heights in obtuse triangles. The reason behind this misconception was expressed by the pre-service teacher with their insufficient knowledge regarding the concept of extension. Although the other specified misconceptions and difficulties were placed in the literature, this one was not specified by other researchers in the available literature.

In addition, analysis of the research findings showed that the pre-service teachers have had the knowledge of students' misconception regarding the relationship between the perimeter and the area of a shape. When the related literature was reviewed, it was seen that the related misconceptions specified by the pre-service teachers were consistent with the determined misconceptions in other studies (Cavanagh, 2008; Moreira \& Contente, 1997). In relation to that, Moreira and Contente (1997) stated that students have a thought such that the area of a figure and its perimeter have a linear relationship, since students do not learn the rationale behind these concepts properly. The pre-service teachers in this study indicated expressions similar to those put forth by Moreira and Contente (1997). For instance, the pre-service teacher Eda explained that students might have the perception that when the area is divided by two, then the perimeter of the shape is also required to be divided by two as well, as if these concepts were related linearly.

As a final difficulty experienced by students and specified by the pre-service teachers regarding the formula of the area of triangle, it was pinpointed that students might have difficulty in understanding the role of two found in the area formula of a triangle. This difficulty emphasized by the pre-service teachers was consistent with the relevant literature (Cavanagh, 2008; Gokdal, 2004; Orhan, 2013). In this respect, it was stated in the literature that students forget to divide the multiplication of the base and its corresponding height by two.

The analysis of the data allowed us to conclude that the pre-service teachers showed their knowledge on students' misconceptions and difficulties regarding the area of triangle by satisfying a great number of students' possible misconceptions and difficulties. In this regard, the courses that the pre-service teachers were enrolled in during their education might have an effect on their knowledge of possible misconceptions and difficulties experienced by students regarding the area of triangle. To clarify, the pre-service teachers were asked to prepare lesson plans with different teaching methods for specific mathematics topics in Methods of Teaching Mathematics I and II courses, and then, these lesson plans were discussed by the instructor and the class. Moreover, the pre-service teachers encountered possible misconceptions of students regarding the learning areas of mathematics and learned to analyze them. In addition to Methods of Teaching Mathematics courses, the two pre-service teachers were enrolled in Nature of Mathematical Knowledge for Teaching course. During this course, the teachers determine possible misconceptions or difficulties on mathematics topics experienced by students. Furthermore, they attempt to estimate possible misconceptions and to prepare their lesson plans by taking these misconceptions into consideration. When the contents of the courses were analyzed, it could be stated that the knowledge of the pre-service teachers on students' misconceptions and difficulties related to the area of triangle might be rooted in the instructions taken from these courses.

During class observations, it was realized that the knowledge of the teacher on possible misconceptions and difficulties experienced by students was important for effective teaching. During a lesson, students may have difficulty in understanding a mathematical concept or they might ask questions involving the misconceptions and difficulties they have. In these circumstances, the teacher should know how to answer to overcome their misconceptions and difficulties. In this regard, there is an implication for teacher educators such that the contents of the courses can be enriched by satisfying some scenarios in 
classroom environments. By means of these scenarios, pre-service teachers can face with students' misconceptions and difficulties and their thoughts about the concepts of mathematics. Hence, preservice teachers can be prepared to overcome these misconceptions and difficulties of students in their future classes.

The context of the present study was limited to the area of triangle. However, other contexts of mathematics learning areas are important and also need to be studied in further studies in a national and international scale. By this way, more information could be gathered about possible misconceptions and difficulties of students on varied mathematics learning areas; hence, effective learning environments could be provided to students.

Author contributions: All authors were involved in concept, design, collection of data, interpretation, writing, and critically revising the article. All authors approve final version of the article.

Funding: The authors received no financial support for the research and/or authorship of this article.

Declaration of interest: Authors declare no competing interest.

Data availability: Data generated or analysed during this study are available from the authors on request.

\section{REFERENCES}

Aksu, Z., \& Konyalığlu, A. (2015). Sınıf öğretmen adaylarının kesirler konusundaki pedagojik alan bilgileri [Pedagogical content knowledge of prospective classroom teachers on fractions]. Kastamonu Eğitim Dergisi, 23(2), 723-738. https://dergipark.org.tr/tr/pub/kefdergi/issue/22599/241424

Aslan Tutak, F., \& Adams, T. L. (2017). A study of geometry content knowledge of elementary preservice teachers. International Electronic Journal of Elementary Education, 7(3), 301-318. https://www.iejee.com/index.php/IEJEE/article/view/82

Ball, D. L., Thames, M. H., \& Phelps, G. (2008). Content knowledge for teaching: What makes it special? Journal of Teacher Education, 59(5), 389-407. https://doi.org/10.1177/0022487108324554

Baturo, A., \& Nason, R. (1996). Student teachers' subject matter knowledge within the domain of area measurement. Educational Studies in Mathematics, 31(3), 235-268. https://doi.org/10.1007/BF00376322

Borko, H., Eisenhart, M., Brown, C. A., Underhill, R. G., Jones, D., \& Agard, P. C. (1992). Learning to teach hard mathematics: Do novice teachers and their instructors give up too easily?. Journal for Research in Mathematics Education, 23(3), 194-222. https://doi.org/10.5951/jresematheduc.23.3.0194

Bukova-Guzel, E. (2010). An investigation of pre-service mathematics teachers pedagogical content knowledge: Example of solid objects. Scientific Research and Essays, 5(14), 1872-1880. https://doi.org/10.5897/SRE.9000173

Burgess, T. A. (2006). A framework for examining teacher knowledge as used in action while teaching statistics. In Proceedings of the Seventh International Conference on Teaching Statistics. https://files.eric.ed.gov/fulltext/ED573184.pdf

Cavanagh, M. (2008). Reflections on measurement and geometry. Reflections, 33(1), 55.

Creswell, J. W. (1998). Qualitative inquiry and research design: Choosing among five traditions. Sage Publications.

Dede, Y., \& Peker, M. (2007). Öğrencilerin cebire yönelik hata ve yanlış anlamaları: Matematik öğretmen adayları'nın bunları tahmin becerileri ve çözüm önerileri [Students' mistakes and misunderstandings about algebra: Pre-service mathematics teachers' estimation skills and solution suggestions]. İlköğretim Online, 6(1), 35-49. https://dergipark.org.tr/tr/pub/ilkonline/issue/8605/107187

Deniz-Yllmaz, D., \& Küçük-Demir, B. (2021) Mathematics teachers' pedagogical content knowledge involving the relationships between perimeter and area. Athens Journal of Education, 8, 1-24. https://doi.org/10.30958/aje.8-4-2

Fidan, Y., \& Türnüklü, E. (2010). İlköğretim 5. sınıf öğrencilerinin geometric düşünme düzeylerinin bazı değişkenler açısından incelenmesi [Examination of geometric thinking levels of primary school 5th grade students in terms of some variables]. Pamukkale Üniversitesi Ĕ̆itim Fakültesi Dergisi, 27, 185-197. https://dergipark.org.tr/tr/pub/pauefd/issue/11116/132940

Fujita, T., \& Jones, K. (2007). Learners' understanding of the definitions and hierarchical classification of quadrilaterals: Towards a theoretical framing. Research in Mathematics Education, 9(1-2), 3-20. https://doi.org/10.1080/14794800008520167

Gökdal, N. (2004). İlköğretim 8. sınıf ve ortaöğretim 11. sınıf öğrencilerinin alan ve hakim konularındaki kavram yanılgıları [The misconceptions of primary school 8th grade and secondary school 11th grade students about domain and judge] (Unpublished master thesis). Gazi University.

Gökkurt, B., Şahin, Ö., Soylu, Y., \& Doğan, Y. (2015). Öğretmen adaylarının geometrik cisimler konusuna ilişkin öğrenci hatalarına yönelik pedagojik alan bilgileri [Pedagogical content knowledge of prospective teachers about student mistakes on geometric objects.]. Ilköğretim Online, 14(1). https://doi.org/10.17051/io.2015.55159

Grossman, P. L. (1990). The making of a teacher: Teacher knowledge and teacher education. Teachers College Press, Columbia University.

Gutiérrez, A., \& Jaime, A. (1999). Preservice primary teachers' understanding of the concept of altitude of a triangle. Journal of Mathematics Teacher Education, 2(3), 253-275. https://doi.org/10.1023/A:1009900719800 
Hershkowitz, R. (1989). Visualization in geometry-Two sides of the coin. Focus on Learning Problems in Mathematics, 11, 61-76. https://www.researchgate.net/publication/287200654_Visualization_in_geometry_two_sides_of_of_the_coin

Hill, H. C., Schilling, S. G., \& Ball, D. L. (2004). Developing measures of teachers' mathematics knowledge for teaching. The Elementary School Journal, 105(1), 11-30. https://doi.org/10.1086/428763

Huang, H. M. E., \& Witz, K. G. (2013). Children's conceptions of area measurement and their strategies for solving area measurement problems. Journal of Curriculum and Teaching, 2(1), 10-26. https://doi.org/10.5430/jct.v2n1p10

Isiksal, M., \& Cakiroglu, E. (2011). The nature of prospective mathematics teachers' pedagogical content knowledge: the case of multiplication of fractions. Journal of Mathematics Teacher Education, 14(3), 213-230. https://doi.org/10.1007/s10857-0109160-x

Kamii, C., \& Kysh, J. (2006). The difficulty of "length $\mathrm{x}$ width": Is a square the unit of measurement? Journal of Mathematical Behavior, 25, 105-115. https://doi.org/10.1016/j.jmathb.2006.02.001

Karaağaç, M. K., \& Köse, L. (2015). Öğretmen ve öğretmen adaylarının öğrencilerin kesirler konusundaki kavram yanılgıları ile ilgili bilgilerinin incelenmesi [Examining the knowledge of teachers and prospective teachers about students' misconceptions about fractions]. Sakarya Üniversitesi Ĕ̆itim Fakültesi Dergisi, (30), 72-92. https://dergipark.org.tr/tr/pub/sakaefd/issue/11235/134244

Karahasan, B. (2010). Preservice secondary mathematics teachers' pedagogical content knowledge of composite and inverse functions [Ph.D. thesis]. Middle East Technical University.

Kılıç, H. (2011). Preservice secondary mathematics teachers' knowledge of students. Turkish Online Journal of Qualitative Inquiry, 2(2), 17-35. https://dergipark.org.tr/en/pub/tojqi/issue/21391/229349

Kubar, A. (2012). Pre-service elementary mathematics teachers' knowledge about definitions of integers and their knowledge about elementary students' possible misconceptions and errors in describing integers [M.S. thesis]. Middle East Technical University.

Kubar, A., \& Cakiroglu, E. (2017). Prospective teachers" knowledge on middle school students" possible descriptions of integers. International Journal of Education in Mathematics, Science and Technology, 5(4), 279-294. https://doi.org/10.18404/ijemst.75211

Lee, E., \& Luft, J. (2008). Experienced secondary science teachers' representation of pedagogical content knowledge. International Journal of Science Education, 30, 1343-1363. https://doi.org/10.1080/09500690802187058

Livy, S., Muir, T., \& Maher, N. (2012). How do they measure up? Primary pre-service teachers' mathematical knowledge of area and perimeter. Mathematics Teacher Education and Development, 12(2), 91-112. https://www.researchgate.net/publication/31 0874246_How_do_they_measure_up_Primary_pre-service_teachers'_mathematical_knowledge_of_area_and_perimeter

Machaba, F. M. (2016). The concepts of area and perimeter: Insights and misconceptions of Grade 10 learners. Pythagoras, 37(1), 304. https://doi.org/10.4102/pythagoras.v37i1.304

Magnusson, S., Krajcik, J., \& Borko, H. (1999). Nature, sources and development of pedagogical content knowledge for science teaching, In J. Gess-Newsome \& N. G. Lederman (Eds.). Examining pedagogical content knowledge: The construct and its implications for science education (pp. 95-132). Kluwer. https://doi.org/10.1007/0-306-47217-1_4

Marks, R. (1990). Pedagogical content knowledge. From a mathematical case to a modified concept. Journal of Teacher Education, 41(3), 3-11. https://doi.org/10.1177/002248719004100302

Moreira, C. Q. \& Contente, M. do R. (1997). The role of writing to foster pupil's learning about area. In Pehkonen, E. (Eds.), Proceedings of the Conference of the International Group for the Psychology of Mathematics Education (21st PME, Lahti, Finland), 3, 256-263.

National Council of Teachers of Mathematics [NCTM], (2000). Principles and standards for school mathematics.

National Council of Teachers of Mathematics [NCTM], (2014). Principles to actions: Ensuring mathematical success for all.

Nur, E., \& Türnüklü, E. (2015). Middle school mathematics teachers' pedagogical content knowledge regarding student knowledge about quadrilaterals. Elementary Education Online, 14(2), 744-756. https://doi.org/10.17051/io.2015.12002

Orhan, N. (2013). An Investigation of private middle school students' common errors in the domain of area and perimeter and the relationship between their geometry self-efficacy beliefs and basic procedural and conceptual knowledge of area and perimeter [M.S. thesis]. Middle East Technical University.

Park, S., \& Oliver, J. S. (2008). Revisiting the conceptualization of pedagogical content knowledge (PCK): PCK as a conceptual tool to understand teachers as professionals. Research in Science Education, 38(3), 261-284. https://doi.org/10.1007/s11165-0079049-6

Rowland, T. (2013) The Knowledge Quartet: The genesis and application of a framework for analysing mathematics teaching and deepening teachers' mathematics knowledge. SISYPHUS Journal of Education, 1(3), 15-43. https://doi.org/10.25749/sis.3705

Rowland, T., Huckstep, P., \& Thwaites, A. (2003). The knowledge quartet. Proceedings of the British Society for Research into Learning Mathematics, 23(3), 97-102.

Rowland, T., Turner, F., Thwaites, A., \& Huckstep, P. (2009). Developing primary mathematics teaching: Reflecting on practice with the Knowledge Quartet. Sage. https://doi.org/10.4135/9781446279571

Runnalls, C., \& Hong, D. S. (2019). “Well, they understand the concept of area”: Preservice teachers' responses to student area misconceptions. Mathematics Education Research Journal, 32(Jul), 629-651. https://doi.org/10.1007/s13394-019-00274-1 
Sahin, O., Gokkurt, B., \& Soylu, Y. (2016). Examining prospective mathematics teachers' pedagogical content knowledge on fractions in terms of students' mistakes. International Journal of Mathematical Education in Science and Technology, 47(4), 531551. https://doi.org/10.1080/0020739X.2015.1092178

Shulman, L. S. (1986). Those who understand: Knowledge growth in teaching. Educational Researcher, 4-14. https://doi.org/10.3102/0013189X015002004

Shulman, L. S. (1987). Knowledge and teaching: Foundations of the new reform. Harvard Educational Review, 57(1), 1-23. https://doi.org/10.17763/haer.57.1.j463w79r56455411

Simsek, N. (2011). Investigation of pedagogical content knowledge of prospective mathematics teachers related to perimeter and area topics in the context of students' difficulties (Unpublished master's thesis). Gazi University, Turkey.

Simsek, N., \& Boz, N. (2015). Sınıf öğretmeni adaylarının uzunluk ölçme konusunda pedagojik alan bilgilerinin öğrenci kavrayışları bağlamında incelenmesi [Examination of primary school teacher candidates' pedagogical content knowledge about length measurement in the context of student comprehension]. Cumhuriyet Uluslararası Ĕ̆gitim Dergisi, 4(3), 10-30. https://doi.org/10.30703/cije.321372

Tamir, P. (1988). Subject matter and related pedagogical knowledge in teacher education. Teaching and Teacher Education, 4(2), 99110. https://doi.org/10.1016/0742-051X(88)90011-X

Tan- Sisman, G., \& Aksu, M. (2009). Seventh grade students' success on the topic of area and perimeter. Elementary Online Education, 8(1), 243-253. https://dergipark.org.tr/tr/pub/ilkonline/issue/8599/107065

Tan- Sisman, G., \& Aksu, M. (2012). Sixth grade students' performance on length, area, and volume measurement. Education $\mathcal{E}$ Science / Egitim ve Bilim, 37(166), 141-154. https://www.researchgate.net/publication/45361044_Sixth_Grade_Students' Performance_on_Length_Area_and_Volume_Measurement

Tan- Sisman, G., \& Aksu, M. (2012). The length measurement in the Turkish mathematics curriculum: Its potential to contribute to students' learning. International Journal of Science and Mathematics Education, 10, 363-385. https://doi.org/10.1007/s10763011-9304-1

Tanisli, D., Kose, N. Y., \& Yavuzsoy, N. (2013). Pre-service mathematic teachers" knowledge of students about the algebraic concepts. Australian Journal of Teacher Education, 38(2), 1-18. https://doi.org/10.14221/ajte.2013v38n2.1

Tekin-Striva, R. (2014). An investigation into middle school mathematics teachers' subject matter knowledge and pedagogical content knowledge regarding the volume of $3 D$ solids (Unpublished doctoral dissertation). Middle East Technical University, Turkey.

Van Steenbrugge, H., Lesage, E., Valcke, M. \& Desoete, A., (2014). Preservice elementary school teachers' knowledge of fractions: a mirror of students' knowledge?. Journal of Curriculum Studies, 46(1), 138-161. https://doi.org/10.1080/00220272.2013.839003

Weston, T. L., Kleve, B., \& Rowland, T. (2012) Developing an online coding manual for the Knowledge Quartet: An international project. Proceedings of the British Society for Research into Learning Mathematics, 32(3), 179-184.

Yenilmez, K., \& Yaşa, E. (2008). İlköğretim öğrencilerinin geometrideki kavram yanılgıları [Primary school students' misconceptions in geometry]. Eskişehir Osmangazi Üniversitesi Eğitim Fakültesi Dergisi, XXI(2), 461-483. https://dergipark.org.tr/tr/pub/uefad/issue/16688/173427

Yeo, J. K. K. (2008). Teaching area and perimeter: Mathematics-pedagogical-content knowledge-in-action [Paper presentation]. 31st Annual Conference of the Mathematis Education Reseach Group of Ustralasia Incorporated (MERGA, 2008). http://hdl.handle.net/10497/14397

Yurtyapan, M., \& Karataş, İ. (2020). Ortaokul matematik öğretmenlerinin üçgenler ve dörtgenler konusuna ilişkin pedagojik alan bilgilerinin incelenmesi [Examination of secondary school mathematics teachers' pedagogical content knowledge on triangles and quadrilaterals]. Turkish Journal of Computer and Mathematics Education, 11(1), 53-90. https://doi.org/10.16949/turkbilmat.443825

Zacharos, K. (2006). Prevailing educational practices for area measurement and students' failure in measuring areas. The Journal of Mathematical Behavior, 25, 224-239. https://doi.org/10.1016/j.jmathb.2006.09.003 